\title{
Rapid Assessment of Needs and Services in Long-Term Care
}

\author{
JANA MALI * \\ VERA GREBENC \\ Faculty of Social Work \\ University of Ljubljana \\ Ljubljana, Slovenia
}

\author{
Original scientific paper \\ UDK: 364.65-053.9:616-082 \\ doi: $10.3935 /$ rsp.v26i2.1603 \\ Received: September 2018
}

With the growing number of older population, our society raises the need to organise various forms of care. In contemporary society, this is considered to be a long-term care system. Since Slovenia does not yet have a longterm care system based on long-term care legislation, while the demographic trends show a great need for it, it is essential to investigate the needs of older people and the possible responses to their needs. By using the method of rapid assessment of needs and services in the Municipality of Straža, we have identified the nature and extent of long-term distress, and sought effective responses to the needs of older people following the modern guidelines of care and substitutions for institutional care. We have found that the population of the municipality is old, the young population is moving away, and the middle generation commutes daily to work outside the municipality. There is no one available to take care of the older population and this trend will continue in the future. The solutions may be found in the organisation of community assistance within the municipality and in regional integration. When planning new services, however, the trend of lowering the quality of well-being of older people, overcoming the prevailing taboos about the phenomena of old age and strengthening the autonomy and power of older people, their social network and introducing modern information and communication technology should be taken into account in the context of social policy.

Key words: older people, welfare, institutions, innovations, long-term care.

\section{INTRODUCTION}

It is predicted that by 2050 the number of older people will exceed the number of young people for the first time in history. Already, every tenth person is aged 60 years or older; the United Nations estimates that by 2050 , one in every five people is likely to be 60 years or older and by 2150 , one in every three (United Nations, 2009). The projections made by the European Union suggest that the proportion of people aged 65 is likely to increase from $18.2 \%$ in 2013 to $28.1 \%$ by 2050 . The number of very old people (defined here as those aged 80 years and above) is projected to increase at an even more rapid pace, more than doubling to reach 57.3 million by 2050 (Eurostat re-

\footnotetext{
* Jana Mali, Faculty of Social Work / Fakulteta za socialno delo, University of Ljubljana / Univerza v Ljubljani, Topniška ulica 31, 1000 Ljubljana, Slovenia / Ljubljana, Slovenija, jana.mali@fsd.uni-lj.si
} 
gional yearbook, 2017). The United Nations projections show that Europe is currently the oldest continent in the world when looking at the 'very-old-age dependency ratio' - the ratio of over 80 years old to the working age population - and will remain so by 2070 . This ratio was equal to $7 \%$ in 2015 but is forecast to rise to $21.5 \%$ by 2070 , while in other continents it is expected to remain below $17 \%$, with Africa at the lowest level (2.7\%) (The 2018 Ageing Report, 2017).

The presented trends dictate changes in the existing systems of care of older people, known as "systems of formal care," which are often informally formed out to family members of older people. Public policy should respond to these changes, which is why, in this context, in the last decade, the need to establish a sustainable system of long-term care has been brought to attention more and more often.

"Long-term care is the system of activities undertaken by informal caregivers (family, friends, and/or neighbours) and/or professionals (health, social, and others) to ensure that a person who is not fully capable of self-care can maintain the highest possible quality of life, according to his or her individual preferences, with the greatest possible degree of independence, autonomy, personal fulfilment, and human dignity." (WHO Ageing and Health Programme \& Milbank Memorial Fund, 2000: 6). Longterm care may be exercised in the home environment, in an institution, in community forms of care, such as day-care centres, temporary care or temporary accommodation. It may be organised either within the public sector or within the private and non-profit sector and is provided in a set of services extending from long-distance help to twenty-four hour personal care seven days a week (Nies et al., 2013: 20).

The proposals by the European Commission to Member States try to reduce the demand for long-term care through preven- tion initiatives, rehabilitation and the use of technology; and create incentives for informal carers to reduce the pressure on formal care services, alongside boosting efficient, cost-effective (formal) care provision at home and in residential care settings (Longterm-Care-in-Europe, 2017). The Operational Program for the implementation of the European Cohesion Policy during the period 2014-2020 (2014) defines the establishment of long-term care as Slovenia's main task in contributing to the economic development of the EU (EUROPE 2020 - A strategy for smart, sustainable and inclusive growth, 2010).

In this contribution, we shall demonstrate how to research the needs and services in long-term care on the local level by using adequate methodology. On the basis of the survey carried out in one of the smaller municipalities in Slovenia, we shall look at the results that may be useful for local policy makers to implement in their own territory or even in relation to policy of European Union. Similar trends may also be expected in EU countries that still have not developed a system of long-term care, i.e. Croatia. Therefore, the implications of the findings of our research may surely be broadly used. The view by Puljiz (2015), stating that, for Croatia, the ageing of the population is a special challenge for social policy, has encouraged us to present the experience of Slovenia as a good case to follow when it comes down to introducing changes in this area.

\section{LONG-TERM CARE AS A NEW FORM OF CITIZENS' CARE}

A demographic change, described by some as the 'demographic alarm' or the 'aging tsunami' is publicly often presented as a threat to the younger population, although increased life expectancy is quite an achievement of our civilisation, since this phenomenon has never been experi- 
enced in the history of humankind (Mali, 2013b, Lymbery, 2005, Wilson, 2001). Besides demographic changes, the number of people with chronic diseases, long-term psychological, mental and social distress, handicap and various weaknesses has also increased, which has, in turn, increased the need for long-term help or support in order to improve independence and quality of life. At the same time, the number of those who can provide help, i.e. economically active population, has decreased. Thus the ratio between those who provide help and those who receive help has radically changed; on the one hand, the risk of people not receiving adequate help and support has increased, and on the other, the burden on people who provide help has increased (Flaker et al., 2008; Filipovič Hrast et al., 2014; Billings et al., 2013).

The change in the ratio of the population that needs help and the population that can provide help are alarming; however, we may take this as an opportunity to search for new forms of harmony and solidarity in society (Flaker et. al, 2011; Mali, 2013a; Nies et al., 2013), therefore long-term care will be of vital importance in providing social stability in the future. Comprehensive systems of long-term care will be essential to meet the needs of older people, reduce inappropriate dependence on acute health services, help families avoid catastrophic care expenditures, and free women to play broader social roles (World health organisation, 2015). In this context, long-term care may be seen as a global issue that concerns humanity as a whole, regardless of the system of health and social security of individual countries.

Long-term care brings about a lot of novelties, not only on the level of providing social security, but also as a completely different paradigm of care that surpasses older schemes of organised care, ways of approaching human distress, status of users and helping processes (Leichsering et al.,
2013). The traditional care of vulnerable population groups is divided among various sectors, with the social and health sector being separate from one another. On the basis of this departing point, the foundations of social and health security are laid out, along with the financing of care, the employment of human resources and the operation of services. By establishing a new pillar of social security and a new network of services, a special field of integrated long-term care can be created, thereby putting an end to the meaningless separation of social and health services and enabling synergies of various professions into common strategies of help and solidarity (Flaker et al., 2008: 22).

In the traditional system of care, help is divided between the informal sector (relatives, neighbours, acquaintances, friends) and the formal sector (people employed to provide care). The unfavourable image of care will be changed by such long-term care that will empower the informal sector with various forms of help and support provided by the formal sector (Tjadens, Colombo, 2011; Brodsky et al., 2003). In terms of continuing help and support, the role of informal caregivers will be equal to the role of formal caregivers. In this context, however, the known facts should not be put aside. Namely, the informal care is predominantly provided by women (Hlebec and Filipovič Hrast, 2017), often with a status of migrant workers (Mali, 2017) who are in an extremely marginalised position (Bajt et al., 2018).

A change in the financing of care also strongly affects the implementation of care, since the users are given the power of decision-making according to their way and style of life and they have a partnership relationship with experts in the helping process, therefore they are not dependant on the power and knowledge of others and are not merely passive recipients of help. Longterm care services stem from the needs of 
people who use these services and who, in turn, define its standards. In the traditional practice of care, standards of care were determined by service providers or professionals, but this only partly covered the needs of people and the necessities of users (Flaker et al., 2008; Leichsenring et al., 2013; Mali et al., 2018). People were provided help according to the offer available on the market, regardless of their life situation. Often, they were forced to accept particular services, even when they did not need them and accepted them, because other forms were not available. The system of long-term care addresses this shortcoming and adapts the offer of services to the needs of people. These needs change constantly, therefore, it may be expected that long-term care will become a flexible and constantly changing system of care. It will need to be based on the knowledge and methods that see people who need help as active co-creators of solutions. Most likely, new methods will need to be developed, in which case the knowledge and experience of people who need long-term care will become indispensable.

It is also relevant to recognise the negative impacts of the existing forms of help provided to older people in community. There are several studies (Flaker et al., 2008; Mali, 2008b; Anttonen and Karsio, 2016) available that look at the elements of institutional care that have a negative impact on the quality of older people's lives. The changing policy trends in the area of help for older people from institutional care to care provided in the home environment may be seen on a worldwide basis from the mid-1990s (Anttonen and Karsio, 2016). Similarly, the more visible development of older people's care in their home environment can also be seen in Slovenia in the area of social care after 1990 (Mali, 2012). In the international sphere, the trends are directed towards the reduction of institutional capacities for older people and the preference of care provided in the home environment and in environments that are similar to that of the home. National documents show that on the declarative level, the trends follow the guidelines towards care provided in the home environment, but financing and legislation still give the advantage to institutional care (Mali et al., 2018).

\section{THE CASE OF RESEARCHING THE NEEDS OF PEOPLE WHO NEED LONG-TERM CARE}

Since the system of long-term care in Slovenia that would be based on the LongTerm Care Act has not been established yet, while the demographic trends show a great need for long-term care, it is essential to clarify the needs of older people and respond to their needs. The response to their needs, in terms of forms of help and services, should be designed in a way as to meet the need for long-term care most effectively.

In Slovenia, the institutional care of older people is one of the most developed forms of care for older people (Mali, 2011, 2014a; Filipovič Hrast et al., 2014; Flaker et al., 2015). The care trends follow the guidelines of providing the longest independent life of older people in the community as possible, staying in their home environment and not in an institution. Considering the needs of older people and the guidelines for their care, it is relevant to find out what possibilities are available in a particular local environment. In this contribution, we present the potential way of assessing the needs and services of older people in the case of the Municipality of Straža.

\section{Research strategy, purpose and aims of the survey}

In the last two decades, researchers from the Faculty of Social Work have been intensively involved in the development of 
community-based research strategies and in planning the response to the needs of older people from a social work perspective (Flaker et al., 2008; Mali, 2008b, 2011; Grebenc, 2014). The major principle of their research strategy is to provide the local governments, citizens and key organisations in a particular community with useful and practical information that will help create meaningful responses to the expressed needs of older people. This research strategy is based on the tradition of qualitative research (Mesec, 1998, 2004; Glasser and Strauss, 1967) and the researchers' experience with rapid assessment and response (Stimson et al., 1998). The research strategy used in the present study is a combination of methods and techniques of epidemiological, ethnographic and action research, complemented with the possibility of using any other method of research used in human sciences (Rafaelič et al., 2015). It is pragmatically designed, not only in the fact that it is useful and applicative, but also that it enables action and activates the community and other interested parties that are affected by a particular phenomenon. It enables the setting of priorities of common operation or operation of individual actors. With the rapid assessment of needs and services, the extent of the phenomenon is defined (epidemiology), followed by its phenomenological characteristics - how people live and, above all, how they react in situations and in what circumstances they find themselves (ethnography). The research is designed in a way as to enable the action of the participants and actors (action research). The main advantage of this contextual research strategy is to provide a closer look at particular and environmental issues of everyday life and to help see those needs as part of concrete situations in a particular environment (Grebenc and Šabić, 2013).

The research presented in this paper was conducted on the invitation of officials from the Municipality of Straža. Straža is a small municipality in the Southern part of Slovenia. The municipality extends over 28.5 $\mathrm{km}^{2}$. In mid-2017, it had 3,870 inhabitants, $19 \%$ of whom were over 65 years of age. The biggest town nearby is Novo mesto.

The purpose and aims of the research were to:

1. assess the extent, the nature and the distribution of long-term distress,

2. assess the level of institutionalisation of long-term distress in the broader area of the Municipality of Straža,

3. find out what the effective response in the community is that could substantiate institutional care,

4. encourage the development of community services and enable people with longterm care needs to live as independently as possible.

\section{Methodology and procedures}

The study was conducted in the area of the Municipality of Straža in October and November 2017 and involved a mixed-method approach combining qualitative and quantitative data collection.

During research, the following was taken into consideration: (1) the existing documents and sources on the town and the region in order to understand the context of the needs and services pertaining to older people's care (statistics, research reports, documents) and (2) sources acquired through field research (group interviews and individual interviews with older people).

The research was conducted in two steps. The first step was associated with group interviews (focus groups) with all key informants from the municipality. In this part, we gained insight into various professional services and organisations that are active in the area of providing help for older people (12 representatives were involved: three representatives of the mu- 
nicipality, the parish priest, the secretary of the parochial Karitas, the community nurse from the community health centre in Novo mesto, the manager of the pharmacy in Straža, the representative of the local organisation of the Union of the Associations for the Values of the National Liberation, the municipal councillor, the manager of the department of local libraries in Novo mesto, the representative of Red Cross and the representative of the Democratic Party of Pensioners). We learned what needs are perceived among older people, what the characteristics of the older population are, in what way help is already provided for them, what obstacles they encounter in their work and how they see the level of organisation of help for older people in the municipality in the future.

On the basis of the first step, we gained insight into the characteristics of the population of older people in the municipality and determined the criteria of sample to conduct interviews. The interviews were the second step of research. The respondents (15 participants) were approached using the snowball method (looking for respondents with a particular combination of characteristics). The sample covered various types of the population and enabled various combinations of factors including: income (the threshold being the amount denoting the risk-of-poverty rate), mobility (independently mobile, partly mobile or immobile), age (three age groups) and marital status (married, widowed). The interviews were all confidential; it was explained to the respondents that quotes from interviews would be used, but without any identifying information.
The sample covered twelve women and three men. The majority were 80 years old or more. As far as their marital status is concerned, the majority were widowed (eleven), three were married and one divorced. The majority (ten) had an income of up to $700 \mathrm{eu}-$ ros (636 eur is at risk-of-poverty rate in Slovenia according Statistical Office of the Republic of Slovenia, 2018.). We spoke mainly with respondents who were still independent.

All interviews (group and individual interviews) were analysed following the method of qualitative analysis by Mesec (1998). Mesec (1998: 102) summarises this method as a research process in which notions are formed, then categories based on these notions and associated in propositions (judgements) are formed, which are then arranged into a systematically and linked theory that reads as a narration on the phenomenon that was the subject of study.

When assessing the context, we used the available statistical data (Statistical Office of the Republic of Slovenia, 2017) and the data from various local and regional documents and reports (e.g. the development of municipality and region).

\section{Research questions and variables}

The heuristic assumption (hypothetical) has been that people's needs cannot be understood or responded to without taking into account their everyday life context, therefore, the development of responses in the community can only be done by using necessary information regarding what people need and how their wishes may be addressed and fulfilled. According to this assumption, eight

Table 1

Characteristics of the sample of individual interviews

\begin{tabular}{clll}
\hline Gender & M (3) & $F(12)$ & \\
\hline Age & below 65 (3) & $65-80(6)$ & above 80 (6) \\
\hline Marital status & married (3) & widowed (11) & divorced (1) \\
\hline Material status & no income (0) & up to $€ 700(10)$ & above $€ 700(5)$ \\
\hline Mobility & independent (10) & partly independent (2) & not independent (3)
\end{tabular}


main categories of everyday life that indicate the needs of people in long-term care were defined (Flaker et al., 2008):

- housing (circumstances of housing and needs according to living conditions),

- work and money (the material context and needs regarding the arrangement of the financial position of an individual),

- contacts (characteristics of a social network and the needs regarding the social inclusion and embeddedness of an individual),

- everyday life (the structure of the day, important routines and needs regarding independence in everyday chores),

- institutionalisation (as an exit from unbearable living distress),

- discontent in interaction (the attitude of society and the environment in relation to older people, the needs regarding explaining the role of the older person in society),

- institutional career (standpoint and view on institutional care and wish to change the existing institutions),

- disembeddedness and affiliation (the need established between the contradicting tendencies to be independent and to belong, determined by influence over the way a person's day is organised, the future, their whole life).

These categories were used as variables. The guidelines for open questionnaires for focus groups and interviews were designed according to these categories and they were used as clusters for qualitative analysis and structure of results.

\section{RESULTS}

\section{The profile of the Municipality of Straža}

The Municipality of Straža is a typically urban town, for which the compact basic network of services and other care units is characteristic, such as a shop, a post office and offices in the centre. The town extends in all directions into organised settlements of residential houses, compact smaller apartment blocks, and larger farms and dwellings close to vineyards on the edge. The town has the characteristics of a combination of village and town architectural style. The houses and apartment blocks are surrounded by gardens that provide basic food self-sufficiency.

The trend perceived in the municipality is the ageing of the population. According to statistical data on the population of the municipality (Statistical Office of the Republic of Slovenia, 2017) 33\% of the population by 2060 will be older, retired people. The portion of the population that are younger than 65 has been getting smaller and smaller, as well as the overall population dwindling in number. This will affect the workload of younger generations when the older population gets large and needs to be cared for. In the decades that follow, the portion of the population over 65 years of age will be joined by the large generation of the inhabitants of Straža that were born in the period of the "baby-boom generation" (born between 1953 and 1962). For at least 40 years, care for older people will be one of more extensive tasks of the municipality. There are 239 inhabitants of Straža that belonged to the age group of 60-65 in 2017, but in the next five years, this group will be larger by 91 people, which represents almost $38 \%$ of the current population. This group, according to health indicators, will still be active and sound, but according to social welfare indicators, the transition to the status of retired people will bring about a substantial change in the living style along with the expected reduction in income. According to the natural demographic trends and the increase of age, it is reasonable to expect that this quite large group will enter the age of eighty years and older in the following 20 or 25 years, when even relatively healthy older people gradually need more help in everyday life. 
The generations of young, active population, which are small in number, will not be able to provide care for children and older people who need long-term care. They will be torn between caring for children and the older, retired population and will become the "sandwich generation" (Lowenstein, 2005; Naiditch et al., 2013). The generations that are now 30 years old will also find it difficult to provide informal help, because it is characteristic for the Municipality of Straža that many young people move to Ljubljana when they begin their studies. The next factor that will have a strong impact on the need for organised long-term care of older people is the absence of an active, working population in town during the day. The data shows that as many as $80 \%$ of the active inhabitants of Straža migrate daily to Novo mesto or Ljubljana for work. This means that not many people that could provide care for their relatives in need of long-term care and help with daily chores remain in town.

We have also found that many older people live in apartment blocks. These are retired generations, among whom there are many migrants that used to work in local factories. Seven of the apartment blocks have 17 people who live alone in their flats and are 80-90 years old. The biggest problem they encounter is that they can no longer use stairs and there are no lifts in their buildings. They are trapped inside their apartment block. Some of them only have contacts with a fellow human being when talking to their neighbours on the balcony. But if they are hearing impaired, even such form of communication is not of much help. They need companionship. The residents are troubled by the lack of cooperation between younger and older residents when it comes to arranging the environment around the building, snow shovelling or cleaning the stairs. Some apartment blocks only house older people who cannot perform these chores by themselves and who do not receive any help from younger people. They feel that helping each other with common chores around the building would encourage a greater feeling of community.

\section{Housing}

In the generation to which our respondents belong, it is characteristic that they built their own homes, in which they still live. They associate memories with their home and moving away would mean an intrusion of privacy and a crumbled sense of life; they would experience moving away as an intrusion on their stability in life (Štambuk, 2001; Mali, 2008a). Our respondents have expressed in focus groups their wish for independence and the ability to make decisions autonomously on where and how to live.

Young families and children often live nearby (but migrate daily due to their work). They are acquainted with their neighbours and ex-co-workers and socialise in the streets, thereby increasing their social inclusion (Filipovič Hrast and Kopač Mrak, 2013) and intergenerational connections (Mali, 2014). The respondents express in interviews the need for help in arranging their home and/or outer environment. We have recognised that older men fear being left alone. They are worried about how they would take care of themselves, because they are not used to house chores. They also hope that those who do help them with these tasks perform them in the same way as they are used to. They feel that moving into an institution or residential care setting is a threat to them, but at the same time, they see it as the only option if they become immobile or gravely ill. They see institutional care as the only possible form of help for people with dementia.

\section{Work and money}

The majority of respondents in interviews were people with vocational or secondary school education. They like to talk 
about their profession and are proud of it in spite of the fact that they are retired. They are known in their municipality for their profession. They have various skills acquired due to their profession, education or hobbies. They use these skills in everyday life, are appreciated for them among their co-residents and are able to stay active in old age because of them.

The majority of respondents receive a pension, therefore their income is low due to their retirement. Their typical replies are: "I live well. If I want something, I can still afford it (holidays, spa treatment, occasional lunch in a restaurant, clothes, shoes, etc.) (I_11_W_82); I manage to make ends meet, but I tend to be more modest (I_06_M_66; I have enough money to cover everyday expenses, but not much money is left for savings." (I_04_W_79).

A few of the respondents in interviews reported that by the end of the month, they don't have much money left, so they cannot save it for unexpected costs (e.g. if a washing machine breaks down). What little remains of their monthly income after they have covered all their expenses is sufficient only for a cup of coffee with friends. We could perceive feelings of shame and anxiety in the responses of those who are forced to live more modestly. The conversation on income shows that those who are poorer hide their poverty from their neighbours.

We found that one third of the retired population in the municipality would not be able to pay for home care. According to the data provided by the Straža Pensioners' Association, which conducted a survey among 93\% of inhabitants older than 69 years in 2013 collected within the project Older people for Higher Quality of Life at Home (Mali et al., 2017), the majority of them $(90 \%)$ state that they do not need any help, but if such help was needed, as many as $30 \%$ of them would not be able to pay for it and 58\% only partly. This means that data on insufficient financial standing of older people in the municipality was already present in 2013. This was probably the consequence of new social legislation that reduced social transfers as reported by Mali and Leskošek (2015).

\section{Contacts}

The structure of older people's social network follows the natural course and gets smaller due to the mortality of peers. Daily and constant migration of social network members increases the feeling of loneliness and abandonment. The reduced peer cooperation and intergenerational harmony only tends to additionally increase such feelings.

On the other hand, it is the very older generation that preserves interpersonal bonds within a community. We have found that many respondents in interviews feel that they still maintain good relations, socialise, spend time together and help each other if anyone is in need. People who have managed to establish strong friendly and neighbourhood relations, can now count on each other. Those who were more active in a community and were involved in various organised forms can now count on such forms of help.

The respondents' contacts with other people are characterised by various milestones in life - events that turn everyday life upside down and demand adaptation. The biggest milestones in life are associated with losing family members and, more particularly, partners (Štambuk, 2017).

\section{Everyday life, daily activities and routines}

Our respondents are involved in various activities and hobbies. In interviews they reported the following activities: craft skills (knitting, crochet, lace-making, sewing, 
woodworking), physical activities (cycling, walking, playing football), mental activities (doing crossword puzzles, writing articles, plays, reading books and newspapers) and social activities (minding grand-children, providing care for a relative in need). The usual daily activities associated with taking care of oneself, including hygiene, meals and keeping a clean and tidy home, are complemented by various hobbies that fill their days. They cherish regular contact with their family, friends and neighbours. They complement or substitute this human contact with listening to the radio and watching television.

They are also attached to their neighbours, who provide not only socialising, but also help within the neighbourhood. The residents help each other especially with gardening. Some adapt their morning routine to drinking coffee and socialising with their neighbours. If their health were to deteriorate, giving them a greater need for help, they would expect their friendship with neighbours to continue.

The respondents also revealed that they need help meeting various requirements of everyday life (help in everyday hygiene, in the household, preparing food, cleaning the flat, as well as socialising). On the basis of the data acquired in focus groups, we can see that $10 \%$ of older people need help with cleaning their flat. The majority of them are over 85 years.

On the basis of our respondents' accounts we may summarise the following needs regarding daily chores and activities: (1) household help (daily chores, cooking); (2) help with gardening and with more extensive chores in the house/flat; (3) errands (trips to the post office, shops, doctor, etc.).

A large share of older people living in Straža need help with transport. At the moment, their relatives provide it. They hope to see the help from the municipality in the future.

\section{Institutionalisation and institutional career}

For older people living in the municipality of Straža who are in need, institutional care is available. The South-eastern region of Slovenia is well serviced with institutional care for older people. Older people's homes in the region provide institutional care for $5.5 \%$ of people older than 65 (Association of Social Institutions of Slovenia, 2018).

The national plans in this area emphasise the following key guidelines: providing individual treatment of users, innovation and constant introduction of improvements in programmes and services of social care as well as encouraging a results-oriented stance that is beneficial for the users. The providers of institutional care, therefore, need to ensure the active role of users in defining their needs, their cooperation in the programme and development of services as well as planning and implementing their services and programmes.

We have discovered that thirty residents of the municipality of Straža reside in older people's homes in Slovenia, while one resident is in an older people's home in Croatia. The highest number of them reside in older people's home in Novo mesto, as this is the one closest to the municipality of Straža. Those who are acquainted with everyday life in this older people's home describe it as inhuman and disorganised. In the same way, the staff attitude towards residents is described by current residents: "If you are dependent on the staff, many things bother you, but above all, it is the fact that you always need to wait for them, because they take their time and they let make it known that you depend on them (I_01_W_70)" reports one of the residents. The residents accept life in an institution because they do not have any other form of help available. 


\section{Discontent in interaction}

The respondents in interviews report that everyone may occasionally find themselves in situations of discomfort. People who need long-term care find themselves in such situations even more often, due to the fact that they depend on other people. For many people it is the attitude of young people that is seen as problematic. They do not feel that young people respect them and many predicaments arise from the lack of interpersonal contact or forms of cooperation. Many predicaments also arise from contact with professionals, because older people perceive their attitude to be patronising. They wish other people (and professionals) would pay more attention to their personal stories and experiences and respect interpersonal differences and uniqueness along with the particularities of individuals when planning help for older people.

\section{Disembeddedness and affiliation}

The respondents in interviews realised they have power and control over their life when they can independently make decisions about their life. Their feeling of power is strengthened with activities that enable older people to prove to themselves and to others that they are independent, autonomous and can take care of themselves. They express the need for independence and belonging and feel that independence, peace and autonomy, versus loneliness, are constantly at stake. They hope that the assistance will be organised and planned in a way that would enable people to have the impact on their life.

A special challenge in maintaining autonomy and impact over their future is the fact that some of the respondents no longer handle their own money. Some of them have trusted paying bills to their relatives. The respondents who live in institution also see a problem with the paying of care being arranged through direct debit payment. Ever since their arrival to the institution, they no longer have anything to do with their money. After their care is paid, they report, there is not much money left.

\section{The needs as perceived by organisations and services in the municipality}

In focus groups, the representatives of organisations and services providers presented their work. Two humanitarian organisations are present in the municipality of Straža (the Red Cross and Karitas). The Red Cross estimates that there are around 20 older people in the municipality who are materially deprived. The Red Cross helps them with aid packages of food and clothes, and organise socialising and meetings. They also help to organise transport. The parish section of Karitas - Vavta perceives that people are ashamed of displaying their need for help (not only material help). When Karitas finds out about such a person in need, they provide material help and socialising. The Pensioners' Association of Straža is very active in the town. They have 630 members for whom various activities are organised: humanitarian, cultural, educational and sport activities. Very agile older people are involved in their activities (approx. 50 members take part in morning exercise). The position of the older people is well known to the local community nursing care centre. Their work is associated with health indications. They pay visits to homes regardless of the needs involved. Also, the data provided by the pharmacy in Straža shows that around 20 people need help with daily chores. There are also as many as $62 \%$ of older people who receive medicine at their home who are above 65 years old. The parish Vavta vas is also involved with older people. They regularly pay visits to around 15 older people (among them, people older than 90) and one disabled person. The Novo mesto Library is also involved in activities 
provided for older people. Currently, they are running the project "Would you like a book to get to you by bike?" and organising readings at people's homes.

\section{DISCUSSION: THE FINDINGS INTENDED FOR THE DEVELOPMENT OF SOCIAL AND POLITICAL ORIENTATION OF LONG-TERM CARE}

The most apparent result of the research was low material situation of older people in the municipality. The particularity of South-eastern region in which our research was conducted is, according to the situation in Slovenia as a country, that those who are employed receive on average a higher income than the rest of the citizen, while the share of those who receive social assistance benefits and those who are unemployed or long-term unemployed is higher than in the country (Regional implementation plan in the area of social protection 2017-2020 in south-eastern statistical region, 2017: 7). In terms of social groups, the high level of poverty-risk indicators also exposes women above 65 years of age and tenants (Statistical Office of the Republic of Slovenia, 2018).

Among the applicants for social assistance benefits in the South-eastern region of Slovenia, the number of retired people is increasing (Regional implementation plan in the area of social protection 2017-2020 in south-eastern statistical region, 2017: 7). With their low pensions, they can no longer pay for basic living costs. According to data from the focus groups, the municipality contributes $65 \%$ of the payment for home care; however, some people cannot pay for the remaining part of full care. The municipality also pays for care in older people's homes for $9-15$ people per year, but estimates that this number will increase in the future. In this particularly small municipality the reasons for concern are also confirmed by the data stating that the share of the recipients of allowance, the unemployed and long-term unemployed is increasing and is higher than in other parts of this region (Statistical Office of the Republic of Slovenia, 2017). Therefore, the inability of relatives to provide financial care for their older family members is increasing.

Although they are not keen on discussing their means for survival, older people in the municipality report that they do not have savings, as they spend all their money on monthly living costs. If they have the possibility to maintain a garden, they help themselves by growing food. They are worried about covering the costs of help either in their home or in an institutional environment. Similar trends were perceived on the national level in 2013 when new social legislation was introduced (Mali and Leskošek, 2015). Poverty pushes older people to a position of dependency and reduces their autonomy and quality of life.

Many people in the municipality conceal their poverty. In this, their relatives also help them. They ask for material help from Karitas or Red Cross with great difficulty. The representatives of these and other organisations (the Pensioners' Association, community-nursing care, pharmacy) are acquainted with cases when people need material help, but reject it.

The contemporary international guidelines ${ }^{1}$ for older people's care emphasise the importance of providing older people's care

\footnotetext{
${ }^{1}$ The Charter of Fundamental Rights of the European Union (2010), the European Charter of Rights and Responsibilities of Older People in Need of Long-term Care and assistance (2010), the European Social Charter-Council of Europe, the UN Recommendations on Economic, Social and Cultural Rights (2006), Madrid Declaration (2010), the UNECE Strategy (Regional implementation of the action plan on ageing, 2002), the Convention on the Rights of People with Disabilities (2008), the Common European Guidelines on the Transition from Institutional to Community-Based Care (2012) (Mali et al., 2018).
} 
in the home environment, preferably where the person has lived their entire life. The guidelines are based on research showing that the quality of life is defined by various indicators: mental and physical health, culture, system of values, expectations, context, possibilities of associating with other people and the expectations, ambitions and goals of every person individually (Gerino et al., 2017; Flaker et al., 2013). If these findings are transferred to the area of older people's care, we may see how important it is to organise care adapted to the living world of an individual. The guidelines are based on the findings that cooperation, involvement in the community and the possibilities of forming relationships with other people have a substantial impact on the quality of life of older people and their resilience. As far as inclusion is concerned, a person needs to have the possibility to get involved physically, form attachments with other people and identify with a group.

Similar findings are reported in our analysis of interviews with older people. The respondents wish to remain in their homes, in their home environment, which they created for themselves in a way that made their life meaningful. By moving into a different living environment, e.g. an institution, we create the image of old age in terms of a period of life that drives people into a position of dependency on other people. Our respondents have also emphasised that they wish to maintain their independence and autonomous decision-making with regard to the place they live as well as the way of living.

With the above, the contemporary information and communication technology may also be of use. However, we have found that residents above 65 years of age are not well-acquainted with it. Most often they use a phone, listen to the radio and watch television. They are not acquainted with various devices that may facilitate older people's lives in their home environment. In our country, the following forms of help are most used: the red button (wireless phone that provides assistance at a distance. It may have additional functions, such as fall detection, home intruder control device, fire detection or tread cushion in front of the bed), various detectors (e.g. water damage, smoke, low temperature, presence in bed), pill distributor (it alarms the user when it is time to take a pill).

With a growing number of older people in a particular living environment and a simultaneously lower amount of young population, the awareness of older people about the relevance of autonomous decision-making is getting more and more relevant. The representatives of "the baby-boom generation" (Bengston et al., 2005) which is getting larger in Slovenia, are aware of the relevance of autonomy. Consequently, they are paying more attention to their position and role in society and are acquainted with their rights and the implementation of these rights, as well as of the potential neglect in decision-making on the national and local levels.

\section{CONCLUSION}

In our research, we have presented the idea to the municipality to open an older people's centre that would enable older people to remain in their home environment for as long as possible. It would be placed in the centre of the municipality, so that older people would be in the centre of the activities that take place in the municipality. The centre would provide the following services: help with basic life chores, meals (at home or in the centre), daily care for people with dementia, a place for socialising among older people and among younger and older people, a place for exchanging experience and interpersonal harmony, short-term accommodation, transport, professional help and counselling, educational training and various activities for active ageing. 
In order to develop help in the area of long-term care, it is essential for a municipality to play a more active role, which was well demonstrated in the case of the Municipality of Straža. For now, this municipality only ensures home help that is provided in the nearby municipality of Novo mesto by the town's older people's home. However, they still fail to accomplish the national aim, which is to enable $3.5 \%$ of involvement of older people above 65 years of age in this form of help (Resolution on the national programme of social care for $2013-2020$, 2013), since help is provided to only $2.7 \%$ of people (Regional implementation plan in the area of social protection 2017-2020 in south-eastern statistical region, 2017). Along with the providers of home help in the region, we need to review the increasing user trends of this service and plan, according to demographic trends, in the development of this form of help. Organisational changes are also possible (e.g. to establish the regional centre for home help that would join the current providers of home care) as well as those pertaining to implementation (e.g. to offer more home-care providers, social services and similar).

New forms of help should be based on the knowledge, skills and experiences of older people and implemented according to their needs. Such guidelines need to be taken into consideration when designing new services, such as activities associated with employment and socialising. In practice, we too often encounter only those activities that teach older people how to acquire new skills (often inadequate for their age) instead of providing those, based of older people's knowledge.

\section{REFERENCES}

Anttonen, A., \& Karsio, O. (2016). Eldercare service redesign in Finland: Deinstitutionalization of long-term care. Journal of Social Service Research, 42(2), 151-166. https://doi.org/10.1080/0 1488376.2015 .1129017
Association of Social Institutions of Slovenia. (2018). Pokritost potreb. Available at http:// www.ssz-slo.si/wp-content/uploads/POKRITOST-RS-28.6.2017.pdf

Bajt, V., Leskošek, V., \& Frelih, M. (2018). Chains of trust: Fear and informal care work in Slovenia. Anthropological notebooks, 24(1), 69-83. Available at http://www.drustvo-antropologov.si/ AN/PDF/2018_1/Anthropological_Notebooks_ XIV_1_Bajt.pdf

Bengston, V. L., Elder, G. H., \& Putney, N. M. (2005). The lifecourse perspective on ageing: Linked lives, timing and history. In M. L. Johnson, V. L. Bengston, P. G. Coleman \& T. B. L. Kirkwood (Eds.), The Cambridge Handbook of Age and Ageing (pp. 493-501). Cambridge: Cambridge University Press.

Billings, J., Leichsenring, K., \& Wagner, L. (2013). Addressing long-term care as a system - objectives and methods of study. In K. Leichsenring, J. Billings \& H. Nies (Eds.), Long-term care in Europe: Improving policy and practice (pp. 3-18). Basingstoke: Palgrave Macmillan.

Brodsky, J., Habib, J., \& Hirschfeld, M. J. (Eds.). (2003). Key policy issues in long-term care. Geneva: World Health Organization.

European Commission. (2010). EUROPE 2020 - A strategy for smart, sustainable and inclusive growth. Brussels: European Commission.

European Network of National Human Rights Institutions. (2017). Long-term care in Europe. Available at http://ennhri.org/Long-term-Carein-Europe

European Union. (2017). The 2018 Ageing Report: Underlying Assumptions and Projection Methodologies. Luxembourg: Publications Office of the European Union.

Eurostat. (2017). Eurostat regional yearbook. Luxembourg: Publications Office of the European Union.

Filipovič Hrast, M., Hlebec, V., Knežević Hočevar, D., Černič Istenič, M., Kavčič, M., Jelenc-Krašovec, S., \& Mali, J. (2014). Oskrba starejših v skupnosti: dejavnosti, akterji in predstave. Ljubljana: Fakulteta za družbene vede.

Filipovič Hrast, M., \& Kopač Mrak, A. (2013). Social exclusion of elderly in Central and Eastern Europe. International Journal of Social Economics, 40(11), 971-989. https://doi.org/10.1108/ IJSE-05-2012-0082

Flaker, V., Mali, J., Kodele, T., Grebenc, V., Škerjanc, J., \& Urek, M. (2008). Dolgotrajna oskrba: Očrt potreb in odgovorov nanje. Ljubljana: Fakulteta za socialno delo. 
Flaker, V., Mali, J., Rafaelič, A., \& Ratajc, S. (2013). Osebno načrtovanje in izvajanje storitev. Ljubljana : Fakulteta za socialno delo.

Flaker, V., Nagode, M., Rafaelič, A., \& Udovič, N. (2011). Nastajanje dolgotrajne oskrbe: ljudje in procesi, eksperiment in sistem. Ljubljana: Fakulteta za socialno delo.

Flaker, V., Rafaelič, A., Bezjak, S., Dimovski, V., Ficko, K., Fojan, D., Grebenc, V., Kastelic, A., Mali, J., Ošlaj, A., Pfeiffer, J., Ramovš, J., Ratajc, S., Suhadolnik, I., Urek, M., \& Žitek, N. (2015). Priprava izhodišč deinstitucionalizacije v Republiki Sloveniji: končno poročilo, verzija 2.2. Ljubljana: Fakulteta za socialno delo.

Gerino, E., Rolle, L., Sechi, C., \& Brustia, P. (2017). Loneliness, resilience, mental health, and quality of life in old age: A structural equation model. Frontiers in Psychology, 8, 2003. https://doi. org/10.3389/fpsyg.2017.02003

Glasser, B., \& Strauss, A. (1967). The discovery of grounded theory. Chicago: Adline.

Grebenc, V. (2014). Understanding the needs of older people: shifting toward more community based responses. Revija za socijalnu politiku, 21(2), 133-160. https://doi.org/10.3935/rsp.v21i2.1187

Grebenc, V., \& Šabić, A. (2013). Ljubljanske zgodbe: biografije navadnih ljudi. Ljubljana: Fakulteta za socialno delo.

Hlebec, V., \& Filipovič Hrast, M. (2018). Characteristics and determinants of intergenerational financial transfers within families using mixed care for elderly people. Društvena istraživanja: časopis za opća društvena pitanja, 27(1), 27-46. https://doi.org/10.5559/di.27.1.02

Leichsenring, K., Billings, J., \& Nies, H. (Eds.). (2013). Long-term care in Europe: Improving policy and practice. Basingstoke: Palgrave Macmillan.

Lowenstein, A. (2005). Global ageing and challenges to families. In M. L. Johnson, V. L. Bengston, P. G. Coleman \& T. B. L. Kirkwood (Eds.), The Cambridge Handbook of Age and Ageing (pp. 403412). Cambridge: Cambridge University Press.

Lymbery, M. (2005). Social work with older people. Context, policy and practice. London: Sage.

Mali, J. (2008a). Od hiralnic do domov za stare ljudi. Ljubljana: Fakulteta za socialno delo.

Mali, J. (2008b). Comparison of the characteristics of homes for older people in Slovenia with Goffman's concept of the total institution. European journal of social work: the forum for the social professions, 11(4), 431-443. https://doi. org/10.1080/13691450802220966
Mali, J. (2011). An example of qualitative research in social work with older people: the history of social work in old people's homes in Slovenia. Collegium antropologicum, 35(3), 657-664. https://hrcak.srce.hr/72152

Mali, J. (2012). Deinstitutionalisation as a challenge for the development of community-based care for older people $=$ Dezinstitucionalizacija kot izziv za razvoj skupnostne oskrbe starih ljudi. Dialogue in praxis: a social work international journal, 1(1-2), 57-69. Available at http://www.dialogueinpraxis.net/pdf.php?pdf=4 fae $583 \mathrm{e} 5 \mathrm{f} 2553 \mathrm{~d} 4$

Mali, J. (2013a). Dolgotrajna oskrba v Mestni občini Ljubljana. Ljubljana: Fakulteta za socialno delo.

Mali, J. (2013b). Social work with older people: The neglected field of social work. Dialogue in praxis, 2(1-2), 23-40. Available at http://dialogueinpraxis.net $/$ index.php?id=5\&a=article $\&$ aid $=26$

Mali, J. (2014). Social work in residential care facilities for older people as a protagonist of changes in community care for older people in Slovenia. In E. N. Arnold (Ed.). Social work practices: Global perspectives, challenges and educational implications (pp. 133-151). New York: Nova Science Publishers.

Mali, J. (2018) The cultural context of long-term care. In H. C. Rogers (Ed.), Social work: Practices, perceptions, challenges (pp. 63-90). New York: Nova Science Publishers.

Mali, J., \& Leskošek, V. (2015). The impact of austerity measures and disintegrating welfare state on social work with older people in Slovenia $=$ Vpliv varčevalnih ukrepov in razpadajoče države blaginje na socialno delo s starimi ljudmi v Sloveniji. Dialogue in praxis: a social work international journal, 4(1-2), 1-22. Available at http://dialogueinpraxis.net $/$ index $\cdot$ php? $i d=5 \& \mathrm{a}=$ article $\&$ aid $=46$

Mali, J., Flaker, V., Urek, M., \& Rafaelič, A. (2018). Inovacije v dolgotrajni oskrbi: primer domov za stare ljudi. Ljubljana: Fakulteta za socialno delo.

Mali, J., Grebenc, V., Flaker, V., Rafaelič, A., Filipović, T., Šabić, A., Peršič, M. L., \& Zaplatar, T. (2017). Hitra ocena potreb in storitev dolgotrajne oskrbe v Občini Straža: končno poročilo. Ljubljana: Fakulteta za socialno delo.

Mesec, B. (1998). Uvod v kvalitativno raziskovanje v socialnem delu. Ljubljana: Visoka šola za socialno delo.

Mesec, B. (2004). A case of grounded theory construction in social work. In J. Fikfak, F. Adam \& D. Gartz (Eds.), Qualitative Research: Different perspectives, emerging trends (pp. 173-186). Ljubljana: Založba ZRC. 
Naiditch, M., Triantafillou, J., Di Santo, P., Carretero, S., \& Hisch Durrett, E. (2013). User perspectives in long-term care and the role of informal carers. In K. Leichsenring, J. Billings \& H. Nies (Eds.), Long-term care in Europe: Improving policy and practice (pp. 45- 80). Basingstoke: Palgrave Macmillan.

Nies, H., Leichsenring, K., \& Mak, S. (2013). The emerging identity of long-term care systems in Europe. In K. Leichsenring, J. Billings \& H. Nies (Eds.), Long-term care in Europe: Improving policy and practice (pp. 19-41). Basingstoke: Palgrave Macmillan.

Puljiz, V. (2015). Starenje stanovništva - izazov socijalne politike. Revija za socijalnu politiku, 23(1), 81-98. https://doi.org/10.3935/rsp.v23i1.1281

Rafaelič, A., Caserman, D., Zupančič, D., Marušič, D., Matkovič, D., Mali, J., Ficko, K., Peternel, M., Nagode, M., \& Flaker, V. (2015). Hitra ocena potreb in storitev za dolgotrajno oskrbo in dezinstitucionalizacijo zavodov za dolgotrajno oskrbo na področju duševnega zdravja in intelektualnih ovir (Dez-Hops). Verzija 1.1. Ljubljana: Fakulteta za socialno delo.

Novo mesto Social work centre. (2017). Regional implementation plan in the area of social protection 2017-2020 in South-eastern statistical region. Novo mesto: Novo mesto Social work centre.

Resolution on the National Programme of Social Protection 2013-2020. Official Journal of the Republic of Slovenia, 39/2013.

Statistical Office of the Republic of Slovenia. (2017). Občina Straža. Available at https://pxweb.stat.si/ pxweb/Database/Obcine/Obcine.asp
Statistical Office of the Republic of Slovenia (2018). Stopnja tveganja revščine v 2017 nekoliko nižja $(13,3 \%)$, prag tveganja revščine višji kot v 2016. Available at https://www.stat.si/StatWeb/ News/Index/7464

Stimson, G. V., Fitch, C., \& Rhodes, T. (1998). The rapid assessment and response guide on injecting drug use (IDU-RAR): Social change and mental health. London: WHO.

Štambuk, A. (2001). Procjena psihičkog stanja starijih osoba u domu umirovljenika skalom SCL-90-R. Društvena istraživanja, 10(3), 503-526. https:// hrcak.srce.hr/20032

Štambuk, A. (2017). Uloga, standardi i kompetencije socijalnih radnika u palijativnoj skrbi. Ljetopis socijalnog rada, 24(1), 119-146. https://doi. org/10.3935/ljsr.v24i1.142

Tjadens, F., \& Colombo, F. (2011). Long-term care: Valuing care providers. Eurohealth, 17(2-3), 13-17.

United Nations. (2009). Population ageing and development. Available at http://www.un.org/esa/population/publications/ageing/ageing2009chart.pdf

WHO Ageing and Health Programme, \& Milbank Memorial Fund. (2000). Towards an international consensus on policy for long-term care of the ageing. Geneva: World Health Organization.

World Health Organization. (2015). World report on Ageing and Health. Available at http:// apps.who.int/iris/bitstream/10665/186463 /1/9789240694811_eng.pdf

Wilson, G. (2001). Understanding old age. London: Sage. 
Sažetak

\title{
BRZA PROCJENA POTREBA I USLUGA U DUGOROČNOJ SKRBI
}

\author{
Jana Mali, Vera Grebenc \\ Fakultet za socijalni rad, Sveučilište u Ljubljani \\ Ljubljana, Slovenija
}

Uz porast starijeg stanovništva, u našem društvu raste potreba za organiziranjem različitih oblika skrbi. U modernom društvu smatra se da je to dugoročni sustav skrbi. Kako Slovenija još uvijek nema dugoročni sustav skrbi utemeljen na dugoročnom zakonodavstvu o skrbi, iako demografski trendovi pokazuju da za to postoji velika potreba, nužno je istražiti potrebe starijih osoba i moguće zadovoljavanje njihovih potreba. Koristeći metodu brze procjene potreba i usluga u općini Straža, identificirali smo prirodu i opseg dugoročnih potreba i iznašli učinkovita rješenja za potrebe starijih osoba slijedeći moderne smjernice u skrbi i zamjenu za institucijsku skrb. Ustanovili smo da je stanovništvo općine staro, da se mlađe stanovništvo iseljava, a sredovječna generacija svakodnevno putuje na posao izvan općine. Nema nikoga tko bi mogao skrbiti o starijima, a taj će se trend nastaviti i u budućnosti. Rješenja se mogu pronaći u organizaciji pomoći unutar općinske zajednice i u regionalnoj integraciji. Ipak, u kontekstu socijalne politike pri planiranju novih usluga treba uzeti u obzir trend smanjivanja kvalitete života starijih osoba, nadilaženje rasprostranjenih tabua o fenomenu starosti $i$ smanjivanju autonomije $i$ moći starijih osoba, njihovu društvenu umreženost i uvođenje moderne informacijske i komunikacijske tehnologije.

Ključne riječi: starije osobe, socijalna skrb, institucije, inovacije, dugoročna skrb. 